\title{
Genetic studies facilitated management decisions on the invasion of the ruddy duck in Europe
}

\author{
Violeta Muñoz-Fuentes • Andy J. Green • \\ Juan José Negro
}

\begin{abstract}
The ruddy duck (Oxyura jamaicensis), a stifftail native to the Americas, was introduced to the UK in the 1950s and has since been recorded in 22 western Palearctic countries. By 2000, the UK population peaked at nearly 6,000 individuals. In 1991, hybridisation with the native and globally threatened (IUCN Endangered) white-headed duck (Oxyura leucocephala), a stifftail restricted to the Mediterranean and Asia, was recorded in Spain and culling of hybrids and ruddy ducks began. Here we report on a series of genetic studies that have enabled and supported management decisions to the benefit of the whiteheaded duck. First, genetic data confirmed that these are two distinct species, each of which is more closely related to other stifftail species. Second, molecular studies indicated that ruddy ducks in Spain, Iceland and elsewhere in Europe were of captive origin and not descendants from vagrants from their native North America. Third, genetic methods were used to distinguish among different hybrid generations in Spain and detected no ruddy duck introgression in birds identified morphologically as white-headed ducks. Collectively, these results supported management decisions to eradicate ruddy ducks from Europe. Subsequently, a control programme reduced the UK population by over $95 \%$ by 2010 , and the arrival of ruddy ducks to
\end{abstract}

V. Muñoz-Fuentes $(\bowtie) \cdot$ A. J. Green · J. J. Negro

Estación Biológica de Doñana, CSIC, Avda.

Américo Vespucio s/n, 41092 Sevilla, Spain

e-mail: violeta.munoz@ebd.csic.es
Spain decreased from 21 birds in 2003 to two sightings in 2010-2011. However, increased efforts to control small ruddy duck populations elsewhere in Europe and Morocco are still required to ensure conservation of the white-headed duck. This case of invasion by hybridization demonstrates that successful control is feasible given early detection followed by a rapid response plan; it also shows the contribution of research to management and that to guarantee the conservation of an endangered native species action may be required in countries outside its distribution range.

Keywords Bern Convention - Conservation · Hybridization · Mitochondrial DNA - Microsatellites · Introns · Policy

The ruddy duck, a threat to the long-term survival of the white-headed duck

The white-headed duck, the only representative of the stifftail ducks (subfamily Oxyurinae) in the Palaearctic, experienced dramatic population declines throughout its range in the twentieth century and is classified as Endangered by the IUCN (BirdLife International 2008). In Spain, the population declined to only 22 individuals in the 1970s, which prompted wetland protection and a hunting ban that enabled the species 
to recover. The case of the white-headed duck has been, in fact, the most remarkable and prompt reversal of a declining trend among Spanish vertebrate populations or species threatened with extinction. In Spain, after this severe bottleneck, the white-headed duck population has fluctuated between 1,600 and 2,500 individuals in the last decade (Hughes et al. 2006; Torres 2012). Population trends in North Africa are unclear. In the eastern Mediterranean and southwest Asia the population has been estimated to have decreased to 5,000-10,000 individuals (Hughes et al. 2006). The reasons for these generalised declines throughout the species' geographical range include habitat loss, competition for food with introduced fish, illegal hunting, lead poisoning and accidental trapping in fishing nets (Hughes et al. 2006).

The celebrated success of the white-headed duck recovery in Spain, however, soon turned into concern when the North American ruddy duck $O$. jamaicensis jamaicensis began to spread in Europe and reached Spain (Anonymous 1993; Green and Hughes 1996; Hughes et al. 2006). First, both species have similar habitat and food requirements. Second, whereas the white-headed duck has been historically restricted to Mediterranean wetlands, the ruddy duck in its native North America inhabits a variety of wetland habitats and climatic zones and it is stable at ca. 500,000 individuals (Wetlands International 2006). In Europe, from its initial appearance in the UK, ruddy ducks subsequently dispersed, reaching Scandinavia, Morocco, the Czech Republic and Iceland, and its population could potentially amount to tens of thousands of individuals. In the UK alone, the ruddy duck population peaked at nearly 6,000 individuals in the early 2000s (Kershaw and Hughes 2002). Third, a potential threat from hybridization was identified in the 1980s (Scott 1982; Anstey 1989) and later became reality when ruddy ducks reached white-headed duck range countries (Spain, Morocco). Therefore, the presence of the ruddy duck in the western Palearctic was identified as the main threat for the white-headed duck's long-term survival (Green and Hughes 1996; Hughes et al. 2006).

\section{International action}

When human actions in one place have severe transboundary effects on biodiversity in others, internationally coordinated plans are needed to address the situation. The white-headed duck exemplifies this situation well. The first International Ruddy Duck workshop, organized in 1993, adopted the goal "to stop and reverse the population and range expansion of the introduced ruddy duck in the western Palearctic, in order to safeguard populations of the white-headed duck" in the Mediterranean and Asia (Anonymous 1993). Subsequent Action Plans (e.g. Green and Hughes 1996; Hughes et al. 2006; Cranswick and Hall 2010) recommended the complete elimination of ruddy ducks before 2015 and a ban on the possession of ruddy ducks in captivity in the western Palaearctic. A considerable effort is being made by European countries in order to fulfil these recommendations (Cranswick and Hall 2010), most notably an extensive control programme in the UK, where the population is largest (see below).

Action to control the ruddy duck population in Europe, however, has not been exempt of controversy. Particularly in the UK, the arrival of the ruddy duck was welcomed by many as an interesting addition to the avifauna (e.g. Zonfrillo 2000). Critics of the ruddy duck control programme led by animal welfare activists, birding groups and journalists, mainly in the UK, argued that ruddy ducks may have arrived in Europe on their own accord. Although no ruddy ducks were observed in Europe before they were introduced to the UK in 1948, vagrants of other duck species from North America are occasionally observed in Europe (Cramp and Simmons 1977). Additionally, there were suggestions in the popular media that ruddy ducks and white-headed ducks hybridized because they were not distinct species.

In Spain, the first ruddy ducks were recorded in 1984 and the first hybrids in 1991 (Torres and MorenoArroyo 2000) (see Fig. 1). Prompt action was taken to remove ruddy ducks and hybrids by selective shooting. Ruddy duck females and hybrids are very difficult to spot amidst a flock of white-headed ducks. A hybrid identification key was produced (Urdiales and Pereira 1993; in Spanish, translated into English and French, and available at http://www.consevol.org/members/ UrdialesPereira_OxyuraKey.pdf) to identify birds based on morphology, plumage characteristics and beak shape. In Spain, hybrid numbers peaked in 1992 and 1993, and 31 were shot in those 2 years, but subsequently not more than six per year were recorded (Fig. 1). In Morocco, hybrids reached almost 20 


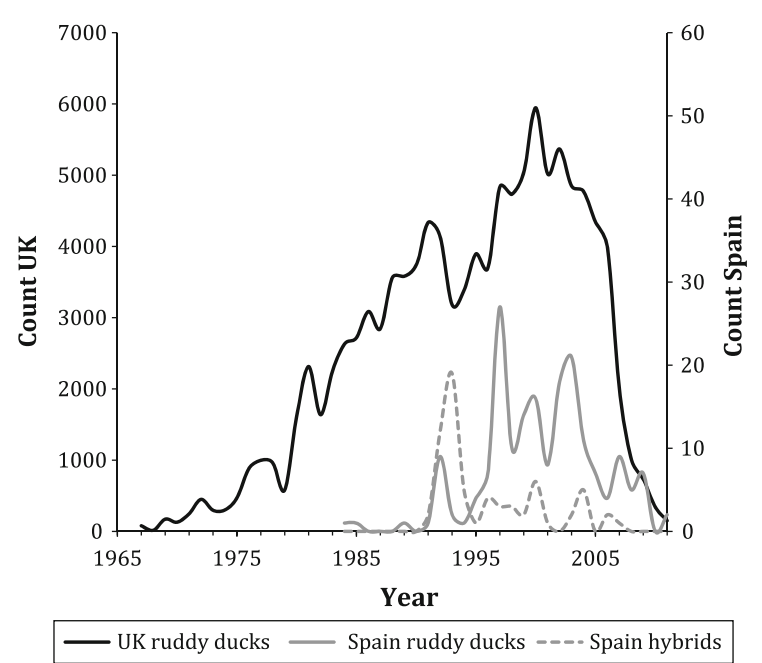

Fig. 1 Population trends of ruddy ducks in the UK and Spain, and hybrids between white-headed duck and ruddy duck in Spain. A decrease of ruddy duck numbers in the UK correlated with a decrease in ruddy duck and hybrid numbers in Spain. (Source Torres and Moreno-Arroyo 2000; Kershaw and Hughes 2002; Cranswick and Hall 2010; Torres 2012; Wetland Bird Survey data.)

individuals in 1998-99 but decreased to almost zero in following years (Cranswick and Hall 2010).

\section{The contribution of genetic studies to the management of the feral ruddy duck in Europe}

Basic biological studies had been conducted on the white-headed duck, such as foraging ecology and habitat selection (e.g. Green et al. 1999; Sánchez et al. 2000). However, knowledge of genetic variability and structure of white-headed ducks or ruddy ducks, as well as information on the hybridization and introgression processes of these two species, were lacking. Indeed, the 1993 workshop recommended DNA analyses "to identify the place of origin of feral populations of ruddy duck in the western Palearctic" and to "determine the parentage and generation of hybrids" (Anonymous 1993). Molecular techniques appeared as an excellent tool to answer a number of questions. First, it was important to clarify the specific status of the ruddy duck and the white-headed duck. Second, the origin of the European population, either from captive-bred individuals or from vagrants from North America, needed to be determined. Third, the development of an assay to molecularly identify hybrids would allow assessment of the accuracy of hybrid morphological identification in the field, the type of crosses occurring in the wild (e.g. are hybrids produced mainly by male ruddy ducks mating with female white-headed ducks, or vice versa? Do hybrids reproduce?), and the efficiency of the control programme (i.e. is there introgression in white-headed duck populations?). Finally, questions about the phylogeography of both species were also tackled.

Molecular data aided the clarification of the specific status of the white-headed duck and the ruddy duck. Although both species can be distinguished morphologically and behaviourally, some critics of the ruddy duck control programme argued that they might not be distinct species because of their reproductive compatibility (viable and fertile hybrids). However, a strict isolation species concept is not applicable to Anatidae, which have a particularly broad capacity to produce fertile hybrids (Kraus et al. 2012; see de Queiroz 1998 for species definitions). Substantial divergence in mtDNA control region sequences and fixed differences between white-headed ducks and ruddy ducks across multiple nuclear introns indicated that they are distinct species (McCracken and Sorenson 2005; Muñoz-Fuentes et al. 2007) and, in fact, the two species are not each other's closest relatives (McCracken and Sorenson 2005). The white-headed duck and the ruddy duck have been geographically isolated for several million years, with absence of gene flow between the two, and have not developed behavioural mechanisms to ensure reproductive isolation.

To determine the origin of ruddy ducks in Europe, mitochondrial DNA and microsatellite data (MuñozFuentes et al. 2005a) were used to study the genetic structure and variability in ruddy ducks from North America, Europe and the contemporary European captive population, descending from the seven North American birds imported to Great Britain in 1948. Muñoz et al. $(2003,2006)$ found that wild ruddy ducks in Europe (sampled populations included Iceland, France, Spain and the UK) were more similar to the captive UK population than to wild birds from North America. These analyses also found that seven birds from North America would suffice to provide the genetic diversity seen today in the European population. Four males and three females were imported to 
Great Britain in 1948 for captive breeding at the Wildfowl \& Wetlands Trust (WWT) in Slimbridge and, between 1953 and 1973, about 90 descendants escaped (Hughes 1997). Therefore, the ruddy ducks found in Europe today originated from the captive population founded by those seven birds, ruling out the possibility that natural arrivals of ruddy ducks from North America to Europe led to the establishment of a European population (Muñoz-Fuentes et al. 2006).

In Spain, an early implementation of a ruddy duck elimination programme attempted to prevent introgression of ruddy duck genes into the white-headed duck population through the elimination of hybrids and ruddy ducks in the wild (identified following the Urdiales and Pereira 1993 key; see above). Muñoz-Fuentes et al. (2007) designed an assay based on molecular markers that allowed the identification of ruddy ducks and whiteheaded ducks, and also the determination of the parental cross that gave rise to hybrids. Notably, backcrosses to both parental species were identified (i.e. the progeny of the cross between an F1 hybrid and either a white-headed duck or a ruddy duck), indicating that some first generation hybrids escaped the control programme and reproduced in the wild. However, an improvement over time in the level of coordination of control efforts between different administrative regions in Spain led to an increase in effectiveness as indicated by the rapid reduction in the number of hybrids recorded after 1993 (Fig. 1). With time, there was a significant increase in the proportion of female ruddy ducks shot (Muñoz-Fuentes et al. 2007); female ruddy ducks are harder to separate from white-headed ducks than males. Importantly, the fact that no introgression of ruddy duck genes was found in 63 morphologically-identified white-headed ducks opportunistically sampled in Spain (found dead, in recovery centres, or ringed during the course of this study), led to the conclusion that both the control methods and field hybrid identification were performing well in reducing hybridization (Muñoz-Fuentes et al. 2007).

Molecular data showed that most F1 hybrids shot in Spain had ruddy duck mtDNA, indicating that a cross between white-headed duck males and ruddy duck females was the most frequent. This disproved initial speculation that hybridization would principally be caused by male ruddy ducks forcing copulations on female white-headed ducks, and underlined the importance of the control team's ability to detect and eliminate ruddy duck females. The hybrid identification key (Urdiales and Pereira 1993) suggested that paternity of hybrids may be identifiable by details of plumage, but molecular data showed this was not the case (authors and the Wildfowl \& Wetland Trust, unpublished data). Interestingly, some contribution to the rapid control of hybridization in Spain may have been through partial infertility. Although the majority of F1 hybrids had ruddy duck mtDNA ( $89 \%$ ), the data showed no confirmation of reproduction of F1 females with ruddy duck mtDNA (Muñoz-Fuentes et al. 2007). This asymmetry would be in accord with Haldane's rule (Haldane 1922) (in hybrids, if only one sex experiences inviability or sterility, it is the heterogametic sex, i.e. females in birds, $\mathrm{ZW}$ ), in that hybrid females with ruddy duck mtDNA may have low fertility or be infertile (Muñoz-Fuentes et al. 2007).

Furthermore, genetic studies have provided additional vital information relevant for white-headed duck conservation. Based on morphology it had been argued that the Spanish population may be fundamentally different from the migratory populations in Asia (Anstey 1989), leading Spanish authorities to be concerned about the potential arrival in Spain of eastern-stock birds spreading from Italy. Although the Spanish white-headed duck population had lower diversity as compared to the past and to other contemporary populations, most likely as a consequence of the demographic bottleneck it went through in the 1970s, neutral markers showed that Spanish and eastern migratory populations cannot be regarded as separate lineages (Muñoz-Fuentes et al. 2005b, 2008). This reduced potential conflicts over the use of captive-bred birds originating from an Asian stock in a reintroduction plan in Italy (Hughes et al. 2006).

\section{Control measures and trans-boundary effects}

International agreements, such as the Bern Convention, provide an obligation to prevent the introduction, and eventually control the establishment, of nonnative invasive species. The above-mentioned results supported actions to control ruddy ducks across Europe. An international initiative has been in place for 20 years (Anonymous 1993; Cranswick and Hall 2010) and has resulted in regular meetings to take decisions for concerted actions to control ruddy ducks in Europe. In the UK, following trials that started in the 1990s and modelling to confirm the viability of the operation (Smith et al. 2005), a nation-wide 
eradication plan was implemented in 2005. The size of the ruddy duck population in the UK has been reduced by $>95 \%$, with winter $2010 / 11$ estimates at 151 individuals (Fig. 1). This decrease correlated with a reduction in ruddy duck numbers in other western Palearctic countries (Cranswick and Hall 2010) and, particularly in Spain, the arrival of ruddy ducks changed from 27 and 21 birds in 1997 and 2003, respectively, to less than 10 per year in 2005 or later (Fig. 1). Combined with continuing efforts in Spain to eliminate ruddy ducks, this has led to a complete lack of observations of hybrids since 2008 (Fig. 1).

However, current small populations of ruddy ducks persist outside the UK and to date the species has been recorded in 22 western Palearctic countries with breeding pairs in nine countries (Cranswick and Hall 2010). Indeed, the numbers of ruddy ducks in mainland Europe now exceed those in the UK, and regular breeding takes place in France, The Netherlands and Belgium since 2005 or earlier, with current population estimates at 220, 60 and 15 birds, respectively (Cranswick and Hall 2010). Although the experience in Spain and the UK demonstrate the success of control actions against the ruddy duck (Cranswick and Hall 2010) and genetic studies show that the whiteheaded duck population is free of introgression (Muñoz-Fuentes et al. 2007), the threat for the white-headed duck still remains in the long term. Ruddy ducks breeding in France, Belgium and The Netherlands could fuel a population expansion eastwards towards other white-headed duck populations in Turkey and beyond. Currently, the distribution range, even if based on very few sightings, has expanded to the east (Czech Republic) and the north (Norway, Sweden, Finland). In Morocco, after no sightings of hybrids since 2003, in 2009 one hybrid was again recorded. Despite efforts made by countries where ruddy ducks breed regularly, acting promptly to control ruddy ducks in a concerted way is needed not only where populations are large, but also where they comprise a few individuals. Acting when populations are small facilitates and reduces management costs (Edelaar and Tella 2012).

\section{Conclusion}

The white-headed duck and the ruddy duck exemplify a rare and successful case in which management actions have been taken in one country to control an invasive species that threatens a native species in another country, despite the political complexities involved. This invasion case also highlights the pivotal role of genetic research to answer specific questions to facilitate management actions. Results from molecular studies guided an early implementation of a culling programme to control an invasive species in time to prevent introgression and the development of a hybrid swarm, which may override species-specific adaptations and, eventually, lead the native species to extinction. An information campaign, implemented early during the culling process, increased public awareness. Molecular studies also provided further valuable information for the conservation of the native endangered species. Applied molecular research and management have enabled conservation of a threatened species, but time will tell whether this is a transient situation. Prompt and increased concerted action is required in other countries besides the UK and Spain to further reduce ruddy duck populations. We urge the implementation of stronger European policy measures to prevent biological invasions and to minimize their impacts. This is an emblematic case that strongly supports the need for development of an effective European Strategy for Invasive Alien Species. A European Union Directive on exotic and alien species is currently being discussed and we urge politicians and interested parties to take immediate action to complete it and make it effective and compulsory within Member States.

Acknowledgments We are grateful to Carlos Gutiérrez, Iain Henderson and Baz Hughes for providing internal reports and data on current estimates of ruddy duck and hybrid numbers in the UK and Spain. We thank Baz Hughes and Montse Vila for a critical reading of the manuscript. VMF was supported by a Spanish National Research Council (CSIC) JAE postdoctoral position. Molecular research was funded by the governments of the Autonomous Communities of Andalucía and Valencia.

\section{References}

Anonymous (1993) International Oxyura jamaicensis workshop, 1-2 March 1993, Arundel, UK. Summary and recommendations. International Waterfowl and Wetlands Research Bureau and JNCC

Anstey S (1989) The status and conservation of the whiteheaded duck Oxyura leucocephala. International Waterfowl and Wetlands Research Bureau (now Wetlands International), Slimbridge 
BirdLife International (2008) Oxyura leucocephala. In: IUCN 2011. IUCN Red List of Threatened Species. Version 2011.2. http://www.iucnredlist.org. Accessed 14 May 2012

Cramp S, Simmons KEL (1977) Handbook of the birds of Europe, the Middle East and North Africa: the birds of the Western Palaearctic. Oxford University Press, Oxford

Cranswick PA, Hall C (2010) Eradication of the ruddy duck Oxyura jamaicensis in the Western Palaearctic: a review of progress and a revised Action Plan 2010-2015. WWT report to the Bern Convention https://wcd.coe.int/ com.instranet.InstraServlet?command=com.instranet.Cmd BlobGet $\&$ InstranetImage $=1757614 \&$ SecMode $=1 \&$ DocId $=$ $1642848 \&$ Usage $=2$. Accessed 20 May 2012

de Queiroz K (1998) The general lineage concept of species, species criteria, and the processes of speciation: a conceptual unification and terminological recommendations. In: Howard D, Berlocher SH (eds) Endless forms: species and speciation. Oxford University Press, Oxford, pp 57-75

Edelaar P, Tella JL (2012) Managing non-native species: don't wait until their impacts are proven. Ibis 154:635-637

Green AJ, Hughes B (1996) Action Plan for the white-headed duck (Oxyura leucocephala) in Europe. In: Heredia B, Rose L, Painter M (eds) Globally threatened birds in Europe Action Plans. Council of Europe Publishing, Strasbourg, pp 119-146

Green AJ, Fox AD, Hughes B, Hilton GM (1999) Time-activity budgets and site selection of white-headed ducks Oxyura leucocephala at Burdur Lake, Turkey in late winter. Bird Study 46:62-73

Haldane JBS (1922) Sex ratio and unisexual sterility in animal hybrids. J Genet 12:101-109

Hughes B (1997) Oxyura jamaicensis. Ruddy duck. In: Hagemeijer WJM, Blair MJ (eds) The EBCC atlas of European breeding birds: their distribution and abundance. T \& AD Poyser, London

Hughes B, Robinson JA, Green AJ, Li ZWD, Mundkur T (Compilers) (2006) International Single Species Action Plan for the conservation of the white-headed duck Oxyura leucocephala. CMS Technical Series No. 13 and AEWA Technical Series No. 8, Bonn

International Wetlands (2006) Waterbird population estimates, 4th edn. Wetlands International, Wageningen

Kershaw M, Hughes B (2002) The winter status and distribution of Ruddy Ducks Oxyura jamaicensis in the UK, 1966/67-1999/2000. WWT Wetlands Advisory Service report to the Central Science Laboratory. Department for Environment, Food and Rural Affairs, London

Kraus RH, Kerstens HH, van Hooft P, Megens H-J, Elmberg J, Tsvey A, Sartakov D, Soloviev SA, Crooijmans RPMA, Groenen MAM, Ydenberg RC, Prins HHT (2012) Widespread horizontal genomic exchange does not erode species barriers among sympatric ducks. BMC Evol Biol $12: 45$

McCracken KG, Sorenson MD (2005) Is homoplasy or lineage sorting the source of incongruent mtDNA and nuclear gene trees in the stiff-tailed ducks (Nomonyx-Oxyura)? Syst Biol 54:35-55

Muñoz V, Green AJ, Negro JJ, Sorenson MD (2003) Population genetics of white-headed ducks and North American ruddy ducks. Threat Waterfowl Special Group News 14:55-58

Muñoz-Fuentes V, Green AJ, Negro JJ, Sorenson MD (2005a) Population structure and loss of genetic diversity in the endangered white-headed duck, Oxyura leucocephala. Conserv Genet 6:999-1015

Muñoz-Fuentes V, Gyllenstrand N, Negro JJ, Green AJ, Vilà C (2005b) Microsatellite markers for two stifftail ducks: the white-headed duck, Oxyura leucocephala, and the ruddy duck, O. jamaicensis. Mol Ecol Notes 5:263-265

Muñoz-Fuentes V, Green AJ, Sorenson MD, Negro JJ, Vilà C (2006) The ruddy duck Oxyura jamaicensis in Europe: natural colonisation or human introduction? Mol Ecol 15:1441-1453

Muñoz-Fuentes V, Vilà C, Green AJ, Negro JJ, Sorenson M (2007) Hybridization between white-headed ducks and introduced ruddy ducks in Spain. Mol Ecol 16:629-638

Muñoz-Fuentes V, Green AJ, Sorenson MD (2008) Comparing the genetics of wild and captive populations of whiteheaded ducks Oxyura leucocephala: consequences for recovery programmes. Ibis 150:807-815

Sánchez MI, Green AD, Dolz JC (2000) The diets of the whiteheaded duck Oxyura leucocephala, ruddy duck $O$. jamaicensis and their hybrids from Spain. Bird Study 47:1000-1011

Scott DA (1982) Managing wetlands and their birds: a manual of wetland and waterfowl management. Proceedings of the third technical meeting on western palearctic migratory bird management, International Waterfowl and Wetlands Research Bureau (now Wetlands International), Slimbridge

Smith GC, Henderson IS, Robertson PA (2005) A model of ruddy duck Oxyura jamaicensis eradication for the UK. J Appl Ecol 42:546-555

Torres JA (2012) Informe Nacional Malvasía 2011. Consejería de Medio Ambiente, Junta de Andalucía (unpublished report)

Torres JA, Moreno-Arroyo B (2000) Presencia de la malvasía canela (Oxyura jamaicensis) en España. Oxyura 10:69-78

Urdiales C, Pereira P (1993) Claves de identificación de $O$. jamaicensis, O. leucocephala y sus híbridos. Instituto Nacional para la Conservación de la Naturaleza (ICONA), Spain.http://www.consevol.org/members/UrdialesPereira_ OxyuraKey.pdf

Zonfrillo B (2000) Ruddy duck. Br Birds 93:394-396 